\title{
Questes
}

\section{L'arbre : éléments de bibliographie}

\section{Mickaël Wilmart et Andrea Martignoni}

\section{(2) OpenEdition}

\section{Journals}

\section{Édition électronique}

URL : http://journals.openedition.org/questes/1671

DOI : 10.4000/questes. 1671

ISSN : 2109-9472

\section{Éditeur}

Les Amis de Questes

\section{Édition imprimée}

Date de publication : 15 mai 2003

Pagination : 21-23

ISSN : 2102-7188

\section{Référence électronique}

Mickaël Wilmart et Andrea Martignoni, «L'arbre : éléments de bibliographie », Questes [En ligne], 4 | 2003, mis en ligne le 01 janvier 2014, consulté le 15 septembre 2020. URL : http:// journals.openedition.org/questes/1671

Ce document a été généré automatiquement le 15 septembre 2020.

(C) Association des amis de «Questes » 


\section{L'arbre : éléments de bibliographie}

Mickaël Wilmart et Andrea Martignoni

NOTE DE L'ÉDITEUR

Cet article n'a pas encore fait l'objet d'une autorisation de publication. 